\title{
Acknowledgments
}

I would like to acknowledge the amazing support I have received from my current institution, the University of Texas at Austin, to complete this book expeditiously. A Tomás Rivera Regents Professorship put at my disposal generous funds to purchase materials and to attend professional conferences to present content from the manuscript. A Research Travel Grant from the Center for European Studies made possible an extended period of archival research in Spain in the summer 2018 that was crucial to the development of this project. Last but certainly not least, a semester leave in spring 2019 released me from all teaching and administrative responsibilities, thus allowing me the time and peaceful state of mind to write the last portion of the manuscript and craft a book proposal.

One section of chapter 1 originally appeared as an article entitled "The Noir Side of Couture: Balenciaga and Luis Marquina's Alta costura (1954)," in Film, Fashion and Consumption vol. 8, issue 2 (2019), and another section will appear in the volume Fashioning Spain (forthcoming from Bloomsbury). A reduced version of chapter 2 appeared as an article entitled "Significant Outfits: Almodóvar Wears Chanel," in Modern Language Notes, vol. 133, no. 2, 2018. I wish to express my gratitude to the publishers for their permission to use material here. I presented material from the manuscript at invited talks at University of Alabama, Tuscaloosa, Durham University, and University of California, Santa Barbara. The feedback I received in those venues helped me refine my arguments and ideas.

I want to express deep gratitude to my editor at the University of Toronto Press, Mark Thompson, for his efficiency and guidance throughout the publication process. I also want to thank the editor of the Toronto Iberic series, Robert Davidson, for his strong support of this project. The two anonymous readers selected by the press were very helpful with their suggestions on the first draft of the manuscript. I also want to thank Joanna Zuckerman Bernstein and Robin Myers for their excellent work editing parts of the manuscript. 
I am beholden to the staff of the Filmoteca Española, the Biblioteca Nacional, and the Museo del Traje in Madrid for their help granting me access to archives and materials over the years. At the Filmoteca, special thanks go to José Luis Estarrona and Trinidad del Río for their continued help identifying films and facilitating film stills for publication. At the Museo del Traje, I want to thank curator Juan Gutiérrez for his kindness in making available the resources of the museum. Christian Mieves deserves a special mention for his help converting film stills into high resolution images.

A number of colleagues at the University of Texas have been extremely supportive of this project. Jossianna Arroyo-Martínez and Héctor Domínguez Ruvalcaba have always offered their friendship and support. Jossianna has also inspired me with her own colourful fashion choices. Luis Cárcamo-Huechante has been my writing partner in crime, as we have set up camp at many coffee shops of East Austin. Sam Vong, now gone to pursue bigger and better endeavours at the Smithsonian Museum, hosted wonderful dinner parties along with Luis. Occasionally, he was also a great clubbing buddy. I wrote a significant chunk of the manuscript while serving as chair of my department. I wish to thank the staff members in Spanish and Portuguese, especially Lisa Mailloux, for making my life easy during that period with their efficiency and also for helping me as top-notch fashion consultants.

Ineed to recognize colleagues and friends from other institutions who have helped me during the writing of this book. Silvia Bermúdez, Ana Corbalán, Santiago Fouz-Hernández, Roberta Johnson, Alfredo Martínez-Expósito, Yajaira Padilla, and Parisa Tadrissi deserve my gratitude for sharing words of advice and bibliographical references, for reading portions of the manuscript, or simply for their comforting words.

Two other people deserve special thanks. As always, my mother has been the best research assistant I could ever have. As a major fashionista, she has deep knowledge of styles, fabric choices, and cuts. Since I don't have formal training in fashion studies, her insights have been super helpful. Our daily Skype chats during lunch break often turned into costume analysis sessions. My partner, Matthew Henderson, was extremely patient with my being perpetually missing in action and in front of the computer. He gave up holding me accountable for my broken promises. I always promise him this will be the last research book I write, and I always change my mind. Books are gone to press, new book projects appear, but he always sticks around. Thank you, pelirrojo.

\section{A Note on Translations}

English translations of film dialogues and quotes from written sources are my own, unless otherwise indicated. 